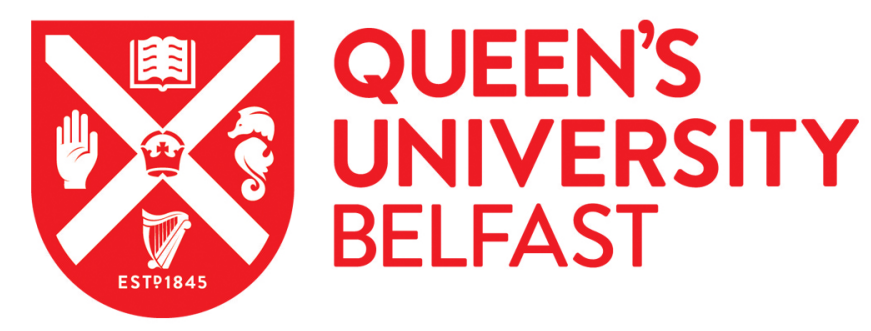

\title{
Integrating Planning and Environmental Protection: An Analysis of post-Brexit Regulatory Styles and Practitioner Attitudes in the UK
}

Cowell, R., Ellis, G., Fischer, T., Jackson, T., Thomas, M., \& Sykes, O. (2020). Integrating Planning and Environmental Protection: An Analysis of post-Brexit Regulatory Styles and Practitioner Attitudes in the UK. Planning Theory and Practice, 21(4), 570-590. https://doi.org/10.1080/14649357.2020.1801819

Published in:

Planning Theory and Practice

Document Version:

Peer reviewed version

Queen's University Belfast - Research Portal:

Link to publication record in Queen's University Belfast Research Portal

Publisher rights

Copyright 2018 Routledge. This work is made available online in accordance with the publisher's policies. Please refer to any applicable terms of use of the publisher.

\section{General rights}

Copyright for the publications made accessible via the Queen's University Belfast Research Portal is retained by the author(s) and / or other copyright owners and it is a condition of accessing these publications that users recognise and abide by the legal requirements associated with these rights.

Take down policy

The Research Portal is Queen's institutional repository that provides access to Queen's research output. Every effort has been made to ensure that content in the Research Portal does not infringe any person's rights, or applicable UK laws. If you discover content in the Research Portal that you believe breaches copyright or violates any law, please contact openaccess@qub.ac.uk. 
This is a pre- copy-editing, author-produced PDF of an article accepted following peer review for publication in Planning Theory and Practice:

\section{Integrating planning and environmental protection: an analysis of post-Brexit regulatory styles and practitioner attitudes in the UK}

Richard Cowell $\mathrm{R}^{1}$, Geraint Ellis $\mathrm{G}^{2}$, Thomas B Fischer ${ }^{3}$, Tony Jackson ${ }^{4}$, Thomas Muinzer ${ }^{5}$ and Olivier Sykes ${ }^{3}$

${ }^{1}$ School of Geography and Planning

Cardiff University

King Edward VII Avenue

Cardiff University CF10 3WA

UK

${ }^{2}$ School of Natural and Built Environment

Queen's University, Belfast

David Keir Building, Stranmillis Road

Belfast, BT9 5AG

${ }^{3}$ Environmental Assessment and Management

Research Centre, Geography and Planning

University of Liverpool

Roxby Building ,74 Bedford Street South

Liverpool, L69 7ZQ, UK

4Town and Regional Planning

School of the Environment

University of Dundee

Perth Road, Dundee DD1 4HN

${ }^{5}$ Aberdeen University Centre for Energy Law

Tower Building

University of Aberdeen

Aberdeen, Scotland

Email: cowellri@cardiff.ac.uk, g.ellis@qub.ac.uk, fischer@liverpool.ac.uk,

a.a.jackson@dundee.ac.uk, thomas.muinzer@abdn.ac.uk,

olivier.sykes@liverpool.ac.uk

Corresponding author: Richard Cowell 


\title{
Integrating planning and environmental protection: an analysis of post-'Brexit' regulatory styles and practitioner attitudes in the UK
}

\begin{abstract}
Debates around the impacts of the UK's exit from the European Union ('Brexit') have exposed the limited critical attention given to how planning systems intersect with environmental protection. This is an important omission, especially given deregulatory pressures on both planning and environment in many countries. In response, this paper uses documentary, interview and focus group data, to conceptualise different regulatory styles governing the environment-planning interface, and assess UK planning practitioner attitudes to EU environmental legislation and scenarios for future change. The data show practitioners largely supporting the fixed standards and robust oversight characteristic of EU environmental regulatory styles, anxious about deregulation, and interested in procedural flexibility. More fundamentally, it also reveals the compromises struck in regulatory design, and the importance of concrete development-environment challenges in constructing arguments for change. Consequently, planning occupies a pivotal position within wider debates about new environmental policy fixes, warranting more extensive professional discussion.
\end{abstract}

Key words: planning, environment, European Union, Brexit, devolution, deregulation 


\section{Introduction}

We are currently at a critical moment, both in terms of looming environmental crises and climate breakdown, but specifically within the UK, of major reappraisal of political culture, constitutional coherence and social values prompted by the 2016 referendum to leave the EU. The subsequent 'Brexit' process has exposed enduring tensions and weaknesses across a range of issues, including environmental protection, sparking concerns about the risks arising from the loss of the EU's environmental protection role (e.g. Burns et al., 2018). Indeed, Brexit has been represented by its proponents as an opportunity to free UK environmental regulation of unduly inflexible EU approaches (Johnson, 2018; Rees-Mogg, 2018).

Such deregulatory pressures are not a recent product of the Brexit debates England's planning system has been subjected to decades of deregulatory action. Nor are they unique to the UK (Balaban, 2012; Gleeson and Low, 2000; Olesen and Carter, 2018), and they span planning and environmental domains (Mol 2012). Yet in various ways we are poorly equipped, analytically, to respond to them. One deficiency concerns our limited understanding of the interface between spatial and land-use planning systems and environmental protection. Although the relationship between these regulatory systems has long been represented as synergistic (Honachefsky, 1999; Millichap, 1993; UNCED, 1992), any connections between them have emerged largely incrementally (Van der Heijden, 2011). Only rarely have policy-makers subjected the relationship between planning and environmental protection to systematic review or reform (for examples, see Jackson and Dixon 2007; RCEP, 2002). This disconnect is mirrored in academic research, with analysts bemoaning that "spatial planning theory is largely "disintegrated" ... from much contemporary planning and environmental practice and wider discourses of sustainability' (Adams et al., 2013, p.375).

Another deficiency concerns our minimal understanding of how key stakeholders and the broader profession conceive the relationship between environmental protection and planning, now and into the future. This is of particular importance, we suggest, because planning occupies a pivotal position within the wider dynamics of change. It is often in planning - where regulatory requirements are translated into concrete development decisions - that the costs and benefits of environmental protection measures can become sharply visible, and encounter greatest contestation.

This paper responds to these debates by making two, interconnected contributions. Firstly, it takes stock of existing literature on the planning-environment relationship, focusing on the interface between EU-derived environmental legislation and UK planning systems, and uses this to map the regulatory styles that each display. This analysis then drives the development of scenarios for how the planning-environment relationship may change in future. These scenarios informed the second contribution, which is a presentation of the results of the first significant study of UK 
practitioners' attitudes towards the interface between planning and EU-derived environmental policy. The findings indicate practitioner concerns about future regulatory styles, especially potential deregulatory shifts post-Brexit, but they also help reveal the tensions to be navigated in any process of regulatory re-design at the planning-environment interface (Inch, 2009).

\section{Methodology and structure}

The analysis carries forward research commissioned by the Royal Town Planning Institute (RTPI: Cowell et al., 2019) designed to investigate the implications of Brexit for the relationship between planning in the UK and EU environmental legislation. Brexit was the issue most commonly cited by RTPI members as a priority for the organisation to explore in the 2017 members survey (Wicks, 2017). To map the planning-EU-environment relationship, the research drew on existing academic studies of the Europeanisation of planning and environmental policy and documentary data sources: environmental governance proposals issued by UK governments since the EU referendum; consultation responses by the RTPI to EU environmental legislation; and commentary on the planning-EU-environment interface in the practitioner press. This analysis was used to derive an initial assessment of how planning and EU environmental legislation intersect and to characterise the regulatory styles they each entail. This in turn informed the scenarios for future change.

This regulatory analysis was accompanied by a two-element qualitative research design. The first element was semi-structured interviews with 21 individuals from public, private and voluntary organisations, and all levels of government, involved with planning and environmental policy, chosen particularly for their prior experience in policy-making as well as implementation. Interviews were conducted between July and December 2018. Interviewees were recruited from the four nations of the UK. Where permitted, interviews were recorded and transcribed; where not, detailed notes were taken. The second element was four focus groups, held in Liverpool, Belfast, Cardiff and Edinburgh during autumn 2018, involving 38 participants in total, drawn from public, private and voluntary organisations engaged in planning and its environmental dimensions. Here, recordings were supplemented by detailed contemporaneous notes, collected and verified between the facilitators. In both interviews and focus groups we posed open-ended questions about attitudes towards EU-derived environmental policy and how it affected respondents' work, as well as on the perceived implications of Brexit, exploring reactions to suggested scenarios for future change.

\section{The planning-environment relationship}


Analysts have long recognised that the ambit and goals of planning have co-evolved with shifting conceptions of 'environment' (Healey and Shaw, 1994). In many countries, planning first emerged as a suite of tools, also sometimes a social movement, to address the public health and 'amenity' problems of urbanisation (Honachefsky, 1999; Ward, 2004). Over subsequent decades, land use or spatial planning systems have acquired roles in delivering or supporting an expanding set of environmental functions, responding to problems at a range of scales, from local to global, in urban and rural settings, onshore and offshore.

Only episodically have these expanding functional connections elicited wider reflection on how planning and environmental action fit together, either conceptually or as forms of regulation. Debates about planning for sustainable development in the 1990s did prompt a major round of theorisation and critique, with much attention given to the status of environmental goals in planning. Analysts questioned whether planning's pervasive utilitarian doctrines of 'balancing' competing goals were compatible with observing environmental limits in the name of long-term sustainability (Owens and Cowell, 2010; Wackernagel and Rees, 1996). Numerous investigations exposed the problematic realities of 'planning for sustainable development' in pro-growth contexts (e.g. Fischer, 1999).

Arguably, theorisation of the planning-environment interface has scarcely moved forward since this period. Most innovation since the 1990s has lain in examining new socio-environmental concepts (e.g. resilience), metrics (from ecological footprint to metabolisms) and tools (Davoudi et al., 2019), rather than considering how planning systems manage or deliver environmental quality as a set of regulatory processes. Such neglect may reflect the procedural emphasis among planning theorists (Adams et al., 2013), the wider negativity towards planning regulation (Inch 2009), and neglect of substantive values more broadly (Campbell and Marshall, 2002; Jepson, 2003). Also obscuring the issue is widespread genuflection towards 'integration', invoking a Panglossian conception of planning and environmental protection working harmoniously together, but concealing harder-edged questions about how integration is achieved, whose goals and practices dominate, and whether anything changes.

This situation has been little affected by the growing influence of the EU; which is surprising given that the EU has developed principles, legislation and governance arrangements that have re-shaped the treatment of many environmental issues across its member states (Burns et al., 2016). The 'Europeanisation' of environmental policy has affected the UK planning system in myriad ways, both directly and indirectly (Bishop et al., 2000; Cowell and Owens 2016; Tewdwr-Jones and Williams, 2001). Table 1 below highlights those EU environmental laws with the greatest effect on planning, showing the breadth of procedural and substantive implications. For some directives, notably EIA and SEA, the planning system is the 
prime delivery agent. For others, planning offers a suite of mechanisms by which goals can be achieved, but without a direct obligation.

\section{<Insert Table 1 somewhere near here>}

The relationship between EU environmental policy and planning has emerged incrementally, with little analysis of how these two sets of institutions actually interact (though see Jones, 2012). Studies of the Europeanisation of environmental policy have occasionally examined planning (Haigh, 1987), but largely through the lens of specific instruments, such as environmental impact assessment (EIA; Jordan, 2002). Meanwhile, the research literature on the EU and planning has focused mainly on how Europeanisation has affected the spatial framing and institutional form of planning (Dühr et al 2010; Tewdwr-Jones and Williams, 2001), while treating environmental aspects as a separate sphere of regulation, downplaying systemic implications. This dearth of attention is problematic, given analysts' conclusions that the effects of the EU on planning policy have been most pronounced in the areas of environmental policy ( van Ravesteyn and Evers, 2004 Wilkinson et al., 1998).

How then should we try to understand the relationship between planning and environmental regulatory systems? There is a diverse conceptual library available, including 'planning cultures' (Dühr et al., 2010; Sanyal, 2005), 'policy styles' (Richardson, 1982) or 'regulatory styles' (Vogel, 1986), each seeking to capture how forms of governing acquire enduring characteristics, derived from the social, economic and political contexts in which they evolved. However, such concepts have tended to exhibit a degree of methodological nationalism - viewing governance forms as characteristic of nation states and internally coherent - that is unhelpful for our subject here. Following Enevoldsen (1997), national styles may not always transcend policy sectors, which can exhibit distinct styles reflecting the constellation of actors, techniques and nature of the issues involved. Tensions may thus arise where multiple sectors interface in the governance of the same object: highly likely with cross-cutting environmental issues.

In this paper we adopt 'regulatory styles' as used by Vogel (1986) to characterise patterns of interaction between regulators, regulations and the regulated, embracing administrative and political domains, including factors such as proclivities towards centralisation and markets. We use 'regulatory styles' largely for its pragmatic descriptive clarity and as a heuristic - for mapping broad distinctions and highlighting prospective change - rather than as the basis of essentialist distinctions on which causal theorising might be based.

The regulatory styles of UK environment and planning 
Ironically perhaps, the UK's prospective departure from the EU triggered a wave of closer attention to the effects of EU environmental policy, including the relationship with planning, prompted in part by concerns at what might be lost. Most analyses conclude that EU membership has driven positive, substantive environmental improvements in a number of areas, notably air, water quality, beach cleanliness, waste management and nature conservation, rescuing the UK from the 1980s status of 'the dirty man of Europe' (Burns et al., 2016; IEEP, 2013). EU measures that are procedural in nature such as EIA and Strategic Environmental Assessment (SEA) have long attracted interest from planning researchers, examining the substantive effects of these techniques on the environmental performance of development (Arts et al., 2013) and on the qualities of decision-making, such as transparency and accountability (e.g. Sheate, 2012).

Causal effects are often traced back to EU legislation, especially key environmental Directives - a legislative form which sets a framework of requirements that Member States are obliged to meet but without dictating the means of doing so. However, the legislation does not function in isolation. A defining feature of the EU environmental acquis is that legislation is backed up by robust governance machinery for monitoring progress, pursuing implementation deficits and, if required, taking enforcement action. This is delivered by the European Commission, the Court of Justice of the EU, and a host of other specialist bodies. This machinery has challenged slippage, held governments to account and cultivated policy learning (Burns et al., 2016; Reid, 2016). While much EU environmental legislation has been developed, in part, in response to international conventions, most such conventions are less detailed in their requirements than EU Directives, and lack mechanisms for securing implementation (Burns et al., 2016), or supportive funding programmes (e.g. LIFE+).

This delineation of the EU 'governance architecture' helps specify key features associated with the EU's own regulatory style for the environment. Legislation has tended to have 'hard edges' (Burns et al., 2016), with firm, substantive environmental targets and standards (e.g. for air quality), that are formal, uniform and relatively strict, with specific time frames for implementation. The overall effect is to facilitate monitoring and enforcement across diverse contexts, to structure the relationship between EU environmental requirements and competing goals, and thereby constrain the discretion of domestic actors. Moreover, EU legislation takes time to make but is durable thereafter, and therefore less vulnerable to short-term political vicissitudes than national action. Commentators also point to the EU's institutionalised commitment to 'a high level of environmental protection', supported by a wider set of principles such as the 'precautionary principle' (Burns et al., 2016). This is not to say that EU environmental legislation has been static, or wholly effective. Moves towards 'framework directives', designed to align goal-orientation with more complex, spatially differentiated problems, have brought some weakening of regulatory 'bite' (Howarth, 2009).Nevertheless, there is sufficient coherence to the 
EU's regulatory style for the environment to distil its key features, as shown in Table 2 , to inform comparison with UK planning.

\section{<Insert Table 2 somewhere near here>}

Broadly speaking, the regulatory style of UK planning is characterised more by discretion and flexibility, reflecting in part its common law traditions (Booth, 2007). This can be observed in the use of broad enabling legislation, deferring substantive detail to policy statements produced by the executive. This gives much freedom for manoeuvre to government, underpinning the considerable centralisation of power that is another characteristic of UK regulatory styles. There is also much flexibility and discretion conferred on local planning authorities e.g. in drawing up plans and making individual development control decisions that ostensibly balance 'material considerations' with public interest objectives (Booth, 2007). Scope for challenging decisions has limits, being confined largely to developers or, where pursued through judicial review, to procedural matters. This contrasts with the outcome-orientation of EU legislation (Reid, 2012) and open scope for complaints. While UK legislation does structure the weight to be attached to environmental matters in planning, EU legislation has tended to add further weight and, sometimes, specific procedural tests (Jones, 2012).

The distinctive features of each regulatory style help to shape the interface between planning and (EU) environmental policy in the UK. In formal constitutional terms the interface is structured by the fact that environment is a 'shared' competence between the EU and Member States but planning remains largely a national matter. EU legislation in this sphere can only be adopted by unanimity (Article 192(2), Treaty on the Functioning of the European Union). The line is more blurred than the high-level constitutional arrangements might suggest (Bond et al., 2016; Haigh, 1987), especially on environmental matters, and arguably should be permeable if planning is to integrate environmental goals. In political terms, the interface is shaped by the tendency of Westminster governments to take a narrow, compliance-based approach to EU environmental legislation (Howarth, 2009; Morphet, 2017), minimising the more substantive EU environmental agenda, for example by criticising EU 'regulatory creep ... imposing additional and expensive requirements on the planning system' (Pickles, 2012). The fact that the UK had a comprehensive planning system in place prior to EU membership has led to questioning of the added value of European environmental legislation; occasionally also by the planning profession (Haigh 1987).

The net result of this approach is that the Europeanization of environmental policy has served both to drive forward environmental protection in planning, but also create a kind of separation (by governance level, and by regulatory style), with tight, formal regulation from the EU interfacing with a UK planning regulatory style favouring discretion, flexibility, and case-by-case balance. The consequence is a 
number of complexities, tensions and fissures in the relationship between two regulatory systems. For example, although the EU has pushed the UK to meet its air quality standards, this has not always been weighted heavily in planning: thus, the traffic-related pollution generated by specific land allocations has tended to be treated as just one material consideration to be balanced against others in making decisions. Successful infraction proceedings brought against the UK government for exceeding EU limit values (Barnes et al., 2018) have led to tightening connections between plan-making and air quality, as witnessed in other EU member states (Van Ravensteyn and Evers 2004).

The EU has also reinforced compliance with the Aarhus Convention on Access to Information, Public Participation in Decision-Making and Access to Justice in Environmental Matters, pressing the UK government on inter alia cost protection for citizen access to justice (Maurici and Moules, 2014). However, the ambit of EU complaints/enforcement action applies only to EU environmental legislation, not UK planning (Jones, 2012), where the UK government has acted to reduce the scope for legal challenge (Rice, 2016). These differences of regulatory style have been amplified and exposed by the intensification, post-2010, of moves in England to deregulate planning and attune it more closely to market growth facilitation (Cowell and Owens 2016). The dynamics have differed in Northern Ireland, Scotland and Wales, as we discuss below.

Regulatory styles and scenarios for change

The discussion above has pulled together key structuring features of EU environmental and UK planning regulatory styles that coalesce at the planningenvironment interface. We turn now to present the regulatory styles dynamically, as scenarios for future change (see Figure 1 below). The scenarios are informed by the disputes surrounding Brexit in the UK, hence the horizontal axis counter-poses 'consistency' with EU regulatory styles with 'sovereignty' for UK institutions, which enlarges the space for more discretionary UK regulatory styles. The vertical axis captures key elements of environmental and planning governance subject to these different styles of regulation - goals and processes - thus positioning the four scenarios. Although the UK's distinctive regulatory traditions in planning might amplify the contrasts with EU practices, the allocation of power for discretion and flexibility is a concern in most planning (Booth 2007) and environmental policy systems, as well as a major focus in debates about deregulation.

\section{$<$ Insert Figure 1 somewhere near here $>$}

One can conceive of a scenario in which UK governments maintain EU environmental regulatory styles, with their emphasis on specific goals and machinery to reinforce implementation, but also extend these practices to cover the 
environmental performance of planning beyond the present boundaries of EU legislation (e.g. Scenario 1 'Firm environmental standards'). Equally, one could see further extension of domestic policy styles, rooted in the flexibility and discretion apparent in UK planning, to reshape aspects of environmental protection previously encompassed by EU legislation (e.g. Scenarios 3 and 4, 'Flexible means' and 'Softening standards').

These scenarios act as a heuristic device, designed to stimulate reflection and discussion and thus necessarily simplify a more nuanced reality. UK governments have not been entirely averse to fixed targets and standards for environmental quality, for example the decarbonisation targets of the Climate Change Act 2008 (Muinzer, 2018). Nor is EU environmental legislation bereft of discretion; Member States have the scope to pursue higher standards. Nevertheless, the scenarios are not entirely speculative, with elements of them already being mobilised by governments across the UK as they try to navigate 'Brexit'. For England, legislation designed to fill the 'environmental governance gap' left by leaving the EU proposes a new environmental watchdog body, to take on board monitoring, complaints handling and enforcement (HM Government, 2020, generating debate as to how far it should embrace planning (Ricketts, 2018). Political desires to create a 'Green 'Brexit' sparked the creation of a new environmental strategy (HM Government, 2018), including statutory environmental goals and targets, the ambit of which project into planning domains. If this resembles Scenario 1, concerns about the prospect of watering down environment protection have not disappeared, not least because the UK government's position in Brexit negotiations is that it 'will choose autonomy over regulatory alignment' with the EU (Pickstone 2020).

Although the right-hand side of Figure 1 is labelled 'becoming more domestic', of course there is already significant differentiation of approach within the UK because of devolution. The UK devolution settlements have given Northern Ireland, Scotland and Wales significant power over planning and environmental policy, but this has been exercised within a framework of minimum common requirements arising from EU membership. Brexit could well therefore lead to further divergence. The governments of Wales and Scotland had already taken a more ambitious approach to various EU environmental Directives than the UK government: notably with waste in Wales and the SEA (Jackson and Illsley 2006) and Water Framework Directives in Scotland. Ongoing EU alignment is an explicit political priority for both (Burns et al., 2018). Meanwhile, in Northern Ireland, devolved institutions were suspended from January 2017 to January 2020, making it hard to discern how post-Brexit environmental governance will be handled by the Northern Ireland Assembly.

Whatever lays ahead, the value of the scenarios as heuristics lies in their capacity to prompt meaningful discussion about the merits of different change trajectories among actors that engage with the planning-environment interface. We now turn 
therefore to our analysis of the qualitative data from planning and environmental practitioners.

\section{Practitioner perspectives}

\section{Existing understanding}

Alongside the limited conceptualisation of the planning-environment interface, there has also been little research into the attitudes of the practitioners in this sphere. As with planning theory, attitudinal research has tended to emphasise procedural concerns, notably planners' attitudes towards publics, participation and collaboration (e.g. Woltjer, 2002). However, understanding the perspective of practitioners is of more than empirical interest, given the important institutional positions that practitioners occupy (Jepson, 2003), hence:

'A fuller conception of planners as reflexive agents operating in such a space, and of the limits to that agency, might provide a better basis to inform ... national policy debates' (Inch, 2009, p.98).

The 'undervalued politics of practice' (op. cit. p.98) offers insights for 'stronger and deeper theories' (Campbell and Marshall, 2002, p.108); in this case of how one might conceive of planning and environmental protection working together.

Although synergies between planning and environmental protection may be widely asserted, the limited evidence available shows practitioners being conflicted. Jepson's survey of US planners found them 'not particularly comfortable' (Jepson 2003,404 ) with conceptions of sustainable development rooted in ecological thinking, preferring to defer to land market pressures rather than environmental constraints. Campbell and Marshall (2002) found younger planners in the UK more comfortable with justifying the role of planning as 'protecting the environment'. Yet practitioners were also found to experience tensions in reconciling the environmental, economic and social dimensions of sustainability, in the context of market-based economies. Lipsky (1980) noted how professionals face dilemmas in enacting any values they might hold in real world situations where competing pressures apply. This is clearly pertinent to planning, which straddles 'contradictory demands from economy and civil society' (Inch 2009,85$)$ that are never fully resolved.

This creates issues in interpreting attitudinal data. A rejection of the value-fact dualism latent in much attitudinal research should guide us to consider how facts and values are interlinked, coming together in dealing with issues of dispute (Boltanski and Thévenot, 2006). Consequently, the views expressed by respondents should not be read simply as extrapolations of held, stable cognitive values onto the 
dilemmas of environment-planning interactions. Instead, value-based or attitudinal remarks should be seen as connected to and grounded in situations that are deemed to be problematic and need resolving. This matters because whether institutional arrangements deal effectively with conflictual situations affects their stability, as a perceived failure to do so may animate arguments for change (Boltanski and Thévenot, 2006). We have taken forward these insights in our data gathering and analysis.

\section{How do (EU) environmental legislation and planning interact?}

Most interviewees and focus group participants perceived that EU membership had underpinned significant substantive improvements in environmental quality and raised levels of environmental protection. Respondents referred to the significant clean-up of rivers and beaches, air quality improvements, and to areas of biodiverse landscape that would otherwise have been lost to development, were it not for 'tighter' EU regulation. Older, domestic environmental legislation (such as the Wild life and Countryside Act 1981) was observed to lack teeth by comparison, and respondents argued that UK governments could have acted of their own accord without EU pressure - but did not do so. On conceptions of the environment, respondents expressed that 'European membership has given a greater focus to targets and thresholds', aiding 'understanding of environmental limits'.

Similarly, respondents also appreciated certain qualitative features of EU legislation, such as its purposive nature, its basis in scientific assessment of some form, the clear objectives and its stability compared to national political levels, especially in England and Northern Ireland. Its value was linked to the wider capacity that EU institutions possess for driving implementation. In particular, respondents pointed to the scope for legal redress, the genuine threat of fines for infractions, and EU action being better insulated from short-termist domestic, political pressures. As an example:

'you only have to look at the UK government's ducking and diving on air quality - without the EU element they'd have just brushed it under the carpet'

For all these reasons, EU regulation was widely described as 'a backstop'.

These positive views were qualified in various ways. For some, the fact that environmental directives set tight constraints and prescriptive legal requirements could itself be a problem, as it diminished the scope for flexible solutions: 'In a discretionary system, you can work your way around these problems but not in a regulatory system'. The tests of the Habitats Directive were most likely to be described as 'too rigid' or 'prescriptive and overly cautious'; unsurprisingly perhaps given that EU nature conservation legislation can translate more directly, through 
planning, into the refusal or modification of planning consents, than other areas of law. Remarks like 'by all means give due importance to the birds but you shouldn't have an absolute ban', and 'I think that it is far too directive rather than discretionary because it doesn't enable people to make a sensible planning decision', characterise a perceived friction between the Habitats Directive and the flexible norms of UK planning regulatory styles. Meeting the procedural requirements of EU Directives, with what was perceived as an emphasis on compliance, was also seen as deflecting attention from achieving enhancement and improvement.

While there was overall support for environmental policies that pursued substantive environmental protection goals, there was more equivocation on the effects of specific procedures, especially EIA and SEA. Perceptions that procedures could be bureaucratic, disproportionate and costly were commonly expressed, linked to problems of interpretation and concerns that positive environmental outcomes were not always apparent. Respondents referred to the uncertainties arising from, for example, screening and scoping decisions attached to EIA, and questioned whether procedures - variously perceived as onerous, or 'slight overkill' - were appropriate in all circumstances. Given that domestic planning legislation already allows local planning authorities to request sufficient environmental information before making a decision (Haigh, 1987) and for public engagement, respondents discussed whether full EIA needed to be so widely used. The perception was that it:

'just bolts on an additional layer of process that frankly just sits on top of the existing transparency arrangements that are at the heart of the planning system'.

However, a marked and consistent feature of the data was the way that many respondents recognised the limits to certain positions and presented counterarguments. One recurring illustration was the trade-offs inherent in the constructing formal, standardised, EU rules. For some, this created interpretative difficulties in applying cross-European requirements to the specific characteristics of the UK planning system, to different categories of development (each with their own regulations) or to the diversity of local circumstances. EU laws were represented as 'one size fits all' procedures (such as the tests for the Habitats Directive), and as disproportionate when applied to 'the small' - i.e. projects or decisions perceived to be small in size or likely to have negligible adverse effects. But, respondents also recognised risks in such lines of thinking. Notionally small projects were observed to still have the potential for major environmental effects, ether individually or cumulatively, which needed to be considered. Having standardised, formal regulatory requirements was seen as driving consistency of practice across local authorities and in national implementation. Indeed, this was a common perception of the value of EU legislation for procedures - that it created consistency, across time and space, and across planning contexts where the weight given to environmental concerns could vary significantly. Arguments for consistency based on EU 
regulatory standards also came from economic sectors like the minerals industry, keen to maintain frictionless, cross-border trade and prevent undercutting: 'we need this regulation to protect legitimate, responsible companies'.

The issue of consistency featured in discussions about the relationship between environmental legislation and planning across the devolved nations. Respondents reported that divergence in planning approaches arising from devolution was an established fact, and that there were advantages to allowing parts of the UK to demonstrate best practice and adopt locally-appropriate solutions. However, at the same time it was recognised that, as the UK left the EU, consistent cross-UK approaches and collaboration would remain very desirable, for example in addressing cross-boundary problems of an environmental or environment-trade nature, making things simple for developers and avoiding a 'race to the bottom' of competitive deregulation.

Interestingly, when the planning-environment interface is viewed through practitioners' perspectives, the notion of clear regulatory styles starts to blur. The qualitative data indicated how the effects exerted by a regulatory style - procedurally and substantively - reflect the social and political processes shaping rules in practice, rather than just the innate, formal properties. Consequently, respondents rarely blamed any difficulties they experienced at the interface between planning and EU-derived environmental policy wholly on the EU or the legislation: 'I think the problems that we've had with EIA and SEA etc, is how we've handled them in the UK'. Respondents pointed instead to an array of intervening factors, including national regulatory transposition and guidance, inconsistencies in planning practice and the skills, competences and intentions of actors on the ground, as summarised in Figure 2. Those that believed EU regulation had under-delivered for the environment also placed the blame on domestic institutions.

\section{$<$ Put Figure 2 somewhere near here>}

Similarly, many responses noted that the formal, procedural requirements of EU Directives provided 'loopholes' or 'more tripwires', which domestic actors then exploited. For some, they created opportunities for 'well-heeled middle classes stopping development', or 'a very nice little earner for lawyers and consultants'. For others, it was developers exploiting any softening of requirements. In turn, a pervasive 'fear of legal challenge' was seen as driving a risk-averse 'over compliance' that helped to make procedures feel unduly bureaucratic. However this too was perceived as a home-grown effect: 'domestic challenge and judicial review, that's not going to go away in a post-'Brexit' world, is it?'; 'the challenge culture is already there'.

Future scenarios 
These themes recur in the patterns of responses to the future scenarios for the planning-environment interface as the UK leaves the EU.

Much positive support was expressed for Scenario 1, Firm environmental standards. Respondents frequently expressed their distrust of domestic politicians, using this as a justification for regulatory arrangements that restricted political discretion. EU-style legislation was supported precisely because it comes with statements of purpose and creates 'red lines' and 'harder edges' (Burns et al., 2016), which UK planning legislation tends to lack.

Respondents were also generally very positive about shifting the regulatory style of planning to focus more heavily on purpose, goals and targets, including raising the material status of environmental standards for air and water quality in planning decisions. It was widely perceived that air quality had historically had a too low profile, lacking political support and skilled practitioners to champion it, and thus action in this area was 'still quite battered by viability arguments' from developers. Respondents also expressed a need to go further, including better integration between environmental quality targets and plan-making, enabling a more strategic role for planning that could embrace cumulative effects.

Where there was equivocation about the merits of Scenario 1, it lay in giving the planning system a responsibility to address issues without the power to do so: any notion of environmental 'safe space' for humanity 'needs to be provided for planners, rather than leaving planners in a vacuum working it out for themselves'. The legal practitioners interviewed also recognised that reinforcing a purposive, goal- or outcome-orientation to decision-making in planning could entail far deeper challenges to the types of interpretive approaches that the UK courts take to applying the law (Reid, 2012).

By comparison, our research encountered less spontaneous engagement with the merits of Scenario 2, Robust Oversight. The exception was Northern Ireland, where the question of 'who would hold decision-makers to account once we left the EU?' was a pervasive concern. The broader quietism on these issues may reflect the fact that most respondents were genuinely ambivalent about the value of procedural checks and public engagement opportunities (as noted by Campbell and Marshall, 2002), which could fetter their own discretion; or at least uncertain as to how they translate into substantively better outcomes. Responses to Scenario 2, that it was 'not improving public engagement', 'not reducing delays' and 'had to be balanced against excessive bureaucracy' indicate the benchmarks by which some judged the merits of future changes.

Interestingly, respondents' support for Scenario 3, Flexible means, was nearly as strong as for Scenario 1. Flexibility was supported because of the nature of 
environmental problems: 'if we're going to meet the very complex goals that we're faced with, particularly in the environmental field, then you have to have that flexibility'. It was also viewed in spatial terms, as allowing responsiveness to the varying circumstances of places, regions and nations, and which 'empowered communities/regions/nations to deliver desired outcomes which respected local conditions'. Support for Scenario 3 may have been buoyed by stating that it operated in the context of firm environmental targets, though a few respondents did recognise that being more flexible about the means by which environmental objectives are achieved could implicitly affect the ends, as we discuss below.

Although there was much positivity for 'removing the straitjacket' and 'tick-boxes' of procedural constraints, respondents were alert to how increased flexibility could be exploited and the risks of procedural simplification. There could be threats to existing valued environmental sites if new flexibilities were not organised as additional to protective measures: 'there is a risk that you lose some very precious habitat ... because you think it can be offset elsewhere'. Again, attitudes towards regulatory styles are interconnected with beliefs about how things would pan out in particular situations, as new regulatory approaches are exploited by developers, planning authorities and government: 'Give them an inch and they'll take a mile!' Greater flexibility was therefore also deemed to require careful controls, including provision for accountability, monitoring and sufficient resources, otherwise it could 'enable complete disregard for the environment'.

For almost all respondents, Scenario 4 - Softening standards- was viewed negatively, describing it as 'my worst nightmare'; 'a real threat' and 'open to abuse'. Many respondents were almost uniformly concerned that this might translate into domestic politicians exercising any new found powers to weaken environmental protections in the pursuit of short-term growth. For some, this reflected perceptions that, since 2010, the Westminster government had come to regard EU environmental requirements as a barrier to development, especially housing. Respondents added that any 'gains' for development from such streamlining could be illusory, insofar as weakening standards and requirements could simply create more uncertainty for developers and lead to more cases ending in the courts. Expressed in outcome terms, 'reducing ambition and rules would lead to environmental and community harm, which eventually would harm the economy'. Our research did encounter a few advocates for radical simplification of planning by removing the 'extra legislation' the EU had created, as means to attract inward investment or to de-clutter planning judgement. These were few in number, tended to be planning lawyers and - as noted above - were not without caveats.

Many of the concerns expressed were UK-wide, but it is also clear that future scenarios for the planning-environment interface could be perceived very differently across the devolved government areas. Perhaps the starkest concerns came from Northern Ireland. Here respondents raised the limited capacity or interest of the 
devolved government in environmental matters, and the weakness of institutional arrangements compared to the rest of the UK (Northern Ireland has no independent environment agency): 'it's always been a rogue state, environmentally'. The prospect of losing what was seen as the 'backstop' of EU environmental protections was viewed as especially problematic, given the integrated nature of the economy of the island of Ireland, the need to manage trans-boundary environmental governance but also the strong economic pressures and pro-development culture. Respondents feared that if Brexit meant Ministers 'get their hands on the legislation there is a concern it would be watered down, it would be a developers' charter', with the prospective expansion of international extractive industries a particular trigger.

In Scotland and Wales, respondents were confident that devolved governments would wish to sustain their commitment to high environmental standards, linked to political desires to continue aligning regulatory standards with those of the EU. In both territories, anti-planning, deregulatory agendas were viewed as more of an English problem. There are nuances, too, in the way that the planning-environment interface was being treated. Proposals for post-'Brexit' environmental governance in Scotland (Scottish Government, 2019) foreground the language of rights, linking Scenarios 1 and 2. In Wales, the Welsh Government has already sought to align its planning system with the long-term goals of its Wellbeing of Future Generations (Wales) Act 2015: an outcome-oriented approach that echoes Scenario 1.

\section{Discussion}

The data show a number of patterns.

Most immediately, the responses reached a clear 'saturation point', across and between both interviews and focus groups, suggesting that the research captured many of the views in circulation. The qualities of the UK and EU regulatory styles derived from the desk research were evidently recognisable to participants and the Scenarios also resonated, especially 1, 3 (both positively) and 4 (negatively). Significantly, many of the views expressed about the planning-environment interface were shared across the different categories of respondents, whether the personnel involved were in policy-making, regulatory or development-promoting roles.

Two other features of the data were also highly important, and link practitioners' attitudes to fundamental issues around how planning and environmental protection fit together as regulatory systems. Firstly, many respondents - individually or in the focus group discussions - recognised that advancing a potential solution (e.g. greater regulatory flexibility) could have costs and risks. As we anticipated, practitioners do not confront conflicts in regulatory styles in the abstract, but in relation to specific practices and dilemmas. This suggests that the concepts that comparative planning analysts use to assess difference and change - in our case 
'regulatory styles - should not necessarily be seen as internally coherent institutional products of particular contextual conditions, but also as compromises between divergent values in which contestable judgements are fixed with varying degrees of durability (Boltanski and Thévenot, 2006). We observed these compromises in a number of areas, such as between formal rules and the space for discretion, with much discussion being directed towards tensions between cross-territorial standardisation, local tailoring and responsiveness to individual cases.

This observation links to how one might conceive of the political and discursive processes of regulatory change, and here a second prominent pattern in the data becomes important. In illustrating criticisms of the present situation with the planning/environment interface and EU legislation, there was a strong tendency for respondents to ground their concerns in a very small number of concrete situations. The issue of disproportionately large EIAs is one example. Although widely perceived as an issue, few respondents attributed this problem to EU requirements, with suggestions pointing instead to causes at other levels (Bond et al., 2016; see Figure 2, above). The other major example is the claim that protective measures for species covered by the Habitats Directive impose excessive costs on developers. Here, the uncertainties and costs created for developers in dealing with potential impacts on Great-crested newts (Triturus cristatus) was a widely and spontaneously referenced signifier for an excessive inflexibility in the EU regulatory style.

This dynamic reinforces the need for researchers and policy-makers to be sensitive to how arguments about concrete situations become generalised into wider arguments for regulatory change. Our evidence suggests that practitioner narratives share some features of the wider narratives around Brexit and the potential evolution of environmental policy. Much of the generalised negative discourse around EU 'red tape' in the environmental sphere and the espoused 'need' for deregulation also emanate from a fairly small number of highly specific issues which endlessly recirculate in the media and political sphere, the newt narrative being one example (Johnson, 2018; Longworth, 2017). A dominant strand of Eurosceptic discourse takes these situations and uses them in constructing wider anti-EU critiques, whether from nationalist or libertarian ideological positions.

Such concerns show how practitioner and political deliberation about the future evolution of the planning-environment interface needs to strike a careful balance. On the one hand there is merit in contemplating the relative qualities of broad regulatory styles and scenarios, in helping with sense-making around the myriad governance issues that affect planning and environmental issues, and giving form to broader trajectories for change. But it is also important to give careful attention to how a given regulatory style may provide effective resolution of particular, disputatious concrete situations. Policy development around great crested newts illustrates what this deliberation might entail. New measures have been trialled that focus less on protecting existing individual newts and more on maintaining overall newt 
populations at a wider scale (Pickstone, 2018), seeking to meet Habitats Directive goals while simplifying procedures for developers - a display, perhaps, of Scenario 3, Flexible Means. The Brexit-related Red Tape Initiative (2018), is remarkable for its conclusions that the scope for flexible development-environment solutions varied between species: in the Initiative's words, bats are 'less flexible than newts' (2018, p.15) in the geography of their lives. What makes it noteworthy is precisely the recognition that issues with the concrete situations around a specific species such as newts should not become a generalised argument for dismantling the robustness of conservation legislation across the board.

\section{Conclusions}

In this paper we have responded to the patchy analytical attention given to the interface between planning and environmental protection by making two contributions. We have provided a conceptualisation of the regulatory styles that interact in this space and a set of scenarios for future change, drawing on distinctions between EU environmental regulation and UK planning. In the UK context, our scenarios helped generate meaningful discussion about the possible future effects of Brexit on the shifting balance between different regulatory styles. Despite the UK grounding, the broad and relatively simple scenarios we have created provide a heuristically useful way of highlighting changes and choices that may be apparent in other jurisdictions (van Ravesteyn and Evers, 2004), and for grasping divergent patterns of change within and between territories, as generated by devolution. Although the framework is necessarily limited in the dimensions it considers, one can see how moves towards or away from scenarios prioritising substantive environmental goals would also configure the scope for other regulatory forms, such as more market-style, incentive-based environmental planning approaches.

The second contribution of our analysis has been to add to our knowledge of UK planning practitioners' perspectives on the planning-environment interface, which has delivered a number of important findings. Our research showed practitioners recognising the role of EU membership in driving substantive environmental improvements, and expressing broad support for UK environmental policy and planning maintaining and cultivating a focus on substantive outcomes, post-Brexit. There was widespread concern about the prospective weakening of environmental standards on leaving the EU, but also much support for greater flexibility in how goals should be achieved.

Moreover, the way that practitioners constructed their reflections and arguments points to more fundamental findings, with relevance beyond the UK's Brexit predicaments. Exploring practitioners' views has indicated that regulatory styles might be better conceptualised as constituted by compromises around enduring 
dilemmas, both in goal conception (between balance-seeking and target/limits-led approaches) and around governance design (such as between common formal standards and the scope for flexibility, or between autonomy and consistency at different scales). In rationalising their views, our respondents also show how pressure for change may be animated and mobilised from the desire to fix specific challenges in reconciling environmental and development pressures. Ironically, for all that certain dominant imaginaries of British planning have conceived it as semidetached from EU environmental policy, the concrete dilemmas of planning practice will be an important arena through which key elements of the legacy of EU environmental policy will be placed under tangible pressure. Such pressures may be apparent in other jurisdictions, whether facing environment policy reforms or deregulation drives. Our research shows how such dilemmas link to enduring questions in the environmental planning field: how far and in what way do we recognise that certain environmental qualities warrant special attention and principled priority?, where should the scope for discretion and flexibility lie?, and how do we govern how discretion is exercised?

In presenting this analysis, we have not sought to challenge the factual or legal veracity of the views expressed, nor establish whether one regulatory style is always preferable to the others (Vogel, 1986). Indeed, if the risks of wholesale deregulation seem obvious, the instigation of tighter environmental goals for planning confronts long-standing criticisms of rationalistic goal-led 'planning for sustainability', that it risks returning planning to an 'ineffective engineering ideal ' (Van der Straaten and Ugelow, 1994, p.127), and stifles creativity (Adams et al., 2013). Yet equally, the need to confront environmental crises raises serious and enduring questions about how 'democratic freedoms' (as exercised by elected representatives, or mobilised by publics) should be melded with the attainment of substantive ecological improvements to deliver politically legitimate action, an issue that unavoidably connects procedural and substantive values. Brexit may have elevated the salience of these issues in the UK, but they deserve wider and more consistent attention by planning researchers and professionals. 


\section{Acknowledgements}

We are grateful for the support of the Royal Town Planning Institute, who commissioned the research on which this paper is based, and to the reviewers and editors from Planning Theory and Practice for their helpful comments on an earlier version of the paper. 


\section{References}

Adams, D., Scott, A. \& Hardman. M. (2013). Guerrilla warfare in the planning system: revolutionary progress towards sustainability? Geografiska Annaler: Series B, Human Geography 95(4), 375-387. https://doi.org/10.1111/geob.12031

Arts, J.., Runhaar, H., Fischer, T. B., Jha-Thakur, U., van Laerhoven, F., Driessen, P.,\& Onyango, V. (2012). The Effectiveness of EIA as an Instrument for Environmental Governance - A Comparison of the Netherlands and the UK. Journal of Environmental Assessment Policy and Management, 14(4), 1-40. https://doi.org/10.1142/9781783268382_0009

Balaban, O. (2012) The negative effects of construction boom on urban planning and environment in Turkey: unravelling the role of the public sector. Habitat International 36(1), 26-35. https://doi.org/10.1016/j.habitatint.2011.05.003

Barnes, J.H., Hayes, E.T., Chatterton, T.J. \& Longhurst, J.W.S (2018). Policy disconnect: A critical review of UK air quality policy in relation to EU and LAQM responsibilities over the last 20 years. Environmental Science and Policy, 85, 28-39. https://doi.org/10.1016/j.envsci.2018.03.024

Bishop, K., Tewdwr-Jones, M. \& Wilkinson, D. (2000). From spatial to local: the impact of the European Union on local planning authority planning in the UK. Journal of Environmental Planning and Management 43(3), 309-334. https://doi.org/10.1080/09640560050010374

Boltanski, L. \& Thévenot, L. (2006) On Justification: Economies of Worth. Princeton University Press.

Bond, A. J., Fundingsland, M. \& Tromans, S. (2016). Environmental impact assessment and strategic environmental assessment in the UK after leaving the European Union. Impact Assessment and Project Appraisal, 34(3): 271274. https://doi.org/10.1080/14615517.2016.1211455

Booth, P. (2007). The control of discretion: planning and the common-law tradition. Planning Theory, 6(2), 127-145. https://doi.org/10.1177/1473095207077585

Burns, C., Jordan, A., Gravey, V., Berny, N., Bulmer, S., Carter, N., Cowell, R., Dutton, J., Moore, B., Oberthür, S., Owens, S., Rayner, T., Scott, J. \& Stewart, B. (2016). The EU Referendum and the UK Environment: An Expert Review. http://environmenteuref.blogspot.co.uk/p/about-us.html

Burns, C., Gravey, V., \& Jordan, A., (2018). UK Environmental Policy Post-'Brexit' : A Risk Analysis, a report for Friends of the Earth, Brexit and Environment, March 2018. http://environmenteuref.blogspot.co.uk/p/about-us.html

Campbell, H. \& Marshall, R. (2002). Values and professional identities in planning practice. in Almendinger, P. and Tewdwr-Jones, M. (eds) Planning Futures: New Directions for Planning Theory, Routledge, pp.93-109.

Cowell, R. \& Owens, S. (2016) 'Land Use Planning', in Burns, C. et al, The EU Referendum and the UK Environment: An Expert Review, http://environmenteuref.blogspot.co.uk/p/about-us.html 
Cowell, R., Ellis, G., Fischer, T., Jackson, T., Muinzer, T. \& Sykes, O. (2019), Environmental Planning after Brexit. Working with the Legacy of EU Environmental Directives, January, Royal Town Planning Institute, https://www.rtpi.org.uk/research/2019/january/environmental-planning-afterbrexit/

Davoudi, S., Cowell, R., White, I. \& Blanco, H. Eds. (2019). The Routledge Companion to Environmental Planning, Routledge.

Dühr, S., Colomb, C. \& Nadin, V. (2010). European Spatial Planning and Territorial Cooperation, Routledge.

Enevoldsen, M. (1997), 'Policy styles and political subcultures', paper presented at the Symposium 'The Innovation of Environmental Policy', Bologna University, Italy, 21-25 July.

Fischer, T.B. (1999) The consideration of sustainability aspects within transport infrastructure related policies, plans and programmes. Journal of Environmental Planning and Management, 42(2): 189-219.

https://doi.org/10.1080/09640569911217

Gleeson, B. and Low, N. (2000) "Unfinished business": neo-liberal planning reform in Australia. Urban Policy and Research 18(1), 7-28. https://doi.org/10.1080/08111140008727821

Haigh, N. (1987). Environmental Assessment - the EC Directive. Journal of Planning \& Environment Law pp.4-20.

Healey, P. \& Shaw, T. (1994). Changing meanings of 'environment' in the British planning system. Transactions of the Institute of British Geographers, 19(4) 425-438. DOI: 10.2307/622833

HM Government (2018). A Green Future. Our 25 Year Plan to Improve the Environment, Crown Copyright.

HM Government (2020). Environment Bill, as introduced $30^{\text {th }}$ January, Parliamentary Copyright House of Commons

Honachefsky, W. (1999). Ecologically Based Municipal Land Use Planning, CRC Press.

Howarth, W. (2009). Aspirations and realities under the Water Framework Directive: proceduralisation, participation and practicalities. Journal of Environmental Law 21(3) 391-417. https://doi.org/10.1093/jel/eqp019

IEEP (Institute for European Environmental Policy) (2013). Report on the Influence of EU policies on the environment, August, IEEP.

Inch, A. (2009). Planning at the crossroads again: re-evaluating street-level regulation of the contradictions in New Labour's planning reforms. Planning, Practice and Research 24(1), 83-101. https://doi.org/10.1080/02697450902742189

Jackson, T. \& Illsley, B. (2006). Strategic Environmental Assessment as a tool of environmental governance: Scotland's extension of the European Union SEA Directive. Journal of Environmental Planning and Management 49(3) 361-383. https://doi.org/10.1080/09640560600598429 
Jackson, T. \& Dixon, J. (2007). The New Zealand Resource Management Act: an exercise in delivering sustainable development through an ecological modernisation agenda. Environment and Planning B: Planning and Design, 34(1), 107-120. https://doi.org/10.1068/b32089

Jepson, E.J. (2003). The conceptual integration of planning and sustainability: an investigation of planners in the United States. Environment and Planning C: Government and Policy 21, 389-410. https://doi.org/10.1068/c0035j

Johnson, B. (2018) 'Uniting for a great Brexit', speech $14^{\text {th }}$ February https://www.gov.uk/government/speeches/foreign-secretary-speech-uniting-fora-great-Brexit

Jones, G. (2012) The impact of environmental law on planning decision-making. Journal of Planning and Environment Law 13 Jordan, A. (2002). The Europeanization of British Environmental Policy. A Departmental Perspective, Palgrave Macmillan.

Lipsky, R. (1980). Street-Level Bureaucracy, Russel Sage Foundation.

Longworth, J. (2017). As Britain breaks free from EU red tape, here are 10 areas that should be first for the chop. Daily Telegraph $13^{\text {th }}$ July.

Maurici, J. \& Moules, R. (2014). The influence of the Aarhus Convention on EU Environmental Law: Part 2. Journal of Planning and Environment Law 2, 181202.

Millichap, D. (1993). Sustainability: A long-established concern of planning. Journal of Planning and Environment Law, 1111-1119.

$\mathrm{Mol}$, A. (2016). The environmental nation state in decline. Environmental Politics 25(1), 48-68. https://doi.org/10.1080/09644016.2015.1074385

Morphet, J. (2017). Beyond 'Brexit'? Policy Press.

Muinzer, T. (2018). Climate and Energy Governance for the UK Low Carbon Transition: The Climate Change Act 2008, Palgrave MacMillan

Olesen, K. and Carter, H., (2018). Planning as a barrier for growth: Analysing storylines on the reform of the Danish Planning Act. Environment and Planning C: Politics and Space, 36(4), pp.689-707. https://doi.org/10.1177/2399654417719285

Owens, S. \& Cowell, R. (2010) Land and Limits: Interpreting Sustainability in the Planning Process, $2^{\text {nd }}$ Edition, Routledge.

Pickles, E. (2012). Written Ministerial Statements, Communities and Local Government, Planning Administration, column 71-72WS, Hansard 6 December.

Pickstone, S. (2018). Central Bedfordshire home to UK's first newt officer. ENDS Report $5^{\text {th }}$ July.

Pickstone, S. (2020) Eustice: "sensible" deal with EU possible without green alignment. ENDS Report $17^{\text {th }}$ February

RCEP (Royal Commission on Environmental Pollution) (2002). Environmental Planning, 23 ${ }^{\text {rd }}$ Report, HMSO.

Red Tape Initiative (2018), Better Regulation for a Post-Brexit Britain, November, RTI. 
Rees-Mogg, J. (2018). Speech, Churcher's College, Petersfield, 25 th January, https://'Brexit' central.com/read-full-text-jacob-rees-mogg-'Brexit' -speech/

Reid, C. (2012). A new sort of duty? The significance of "outcome" duties in the climate change and child poverty acts. Public Law, vol. 2012, no. 4, pp. 749767.

Reid, C. (2016). Brexit : challenges for environmental law. Scots Law Times, vol.27, pp. 143-147.

Rice, L. (2016). Judicial review reform and the erosion of public value. Town and Country Planning, August, 337-340.

Richardson, J. ed. (1982). Policy Styles in Western Europe, London: George Allen and Unwin.

Ricketts, S. (2018). 'Brexit, planning and the environment: key questions', EG 13 October, 78-79.

Sanyal, B. ed. (2005). Comparative Planning Cultures, Routledge.

Scottish Government (2019). Consultation on Environmental Principles and Governance in Scotland, February, Scottish Government: Edinburgh.

Sheate, W. (2012). Purposes, paradigms and pressure groups: accountability and sustainability in EU environmental assessment, 1985-2010. Environmental Impact Assessment Review 33, 91-102. https://doi.org/10.1016/j.eiar.2011.11.001

Tewdwr-Jones, M. \& Williams, R.H. (2001). The European Dimension of British Planning, Spon Press.

UNCED (United National Conference on Environment and Development) (1992) Agenda 21: The United Nations Programme of Action from Rio; United Nations Department of Public Information.

Van der Heijden, J. (2011). Institutional layering: a review of the use of the concept. Politics 31(1), 9-18. https://doi.org/10.1111/j.1467-9256.2010.01397.x

Van der Straaten, J..\& Ugelow, J. (1994). 'Environmental policy in the Netherlands: change and effectiveness', in Wintle, M. and Reeve, R., Eds Rhetoric and Reality in Environmental Policy. The Case of the Netherlands in Comparison with Britain, Ashgate: Aldershot, UK.

Van Ravesteyn, N. \& Evers, D. (2004). Unseen Europe: A Survey of EU Politics and its Impact on Spatial Development in the Netherlands, Netherlands Institute for Spatial Research: The Hague.

Vogel, D. (1986). National Styles of Regulation. Environmental Policy in Great Britain and the United States, Cornell University Press: Ithaca.

Wackernagel, M. and Rees, W. (1996). Urban Ecological Footprints: Why cities cannot be sustainable and why they are key to sustainability. Environmental Impact Assessment Review 16, 223-248.

Ward, S.V. (2004). Planning and Urban Change. London: PCP.

Wicks, S. (2017) 'Insight: the RTPI Members Survey 2017', The Planner, 14 ${ }^{\text {th }}$ December

Wilkinson, D., Bishop, K. \& Tewdwr-Jones, M. (1998). The Impact of the EU on the UK Planning System, a report for DETR, DETR. 
Woltjer, J. (2002). The "public support machine": notions of the function of participatory planning by Dutch infrastructure planners. Planning Practice and Research 17(4), 437-453. https://doi.org/10.1080/02697450216358 


\begin{tabular}{|c|c|c|}
\hline \multicolumn{3}{|c|}{ EU directives with mainly substantive environmental requirements } \\
\hline Directive & $\begin{array}{l}\text { Specified goals } \\
\text { (and procedural elements) }\end{array}$ & Main issues for planning \\
\hline $\begin{array}{l}\text { Ambient Air Quality } \\
\text { Directive(2008/50/EC) }\end{array}$ & $\begin{array}{l}\text { sets legally binding limits for } \\
\text { concentrations in outdoor air of } \\
\text { major air pollutants that impact } \\
\text { public health } \\
\text { (Air Quality Management Areas) }\end{array}$ & $\begin{array}{l}\text { Making air quality implications of } \\
\text { development material to plan-making } \\
\text { and development control. AQMA } \\
\text { contributed to/taken into account. }\end{array}$ \\
\hline $\begin{array}{l}\text { Birds Directives } \\
\text { (2009/147/EC) }\end{array}$ & $\begin{array}{l}\text { the protection of specified bird } \\
\text { species at a favourable } \\
\text { conservation status }\end{array}$ & $\begin{array}{l}\text { Incorporating Special Protection Areas } \\
\text { in development plans and instituting } \\
\text { protective policies }\end{array}$ \\
\hline $\begin{array}{l}\text { Habitats } \\
\text { Directive(92/43/EEC) }\end{array}$ & $\begin{array}{l}\text { to enable the protection of specified } \\
\text { animals and habitats at a favourable } \\
\text { conservation status }\end{array}$ & $\begin{array}{l}\text { Incorporating Special Areas of } \\
\text { Conservation in development plans } \\
\text { and instituting protective policies }\end{array}$ \\
\hline $\begin{array}{l}\text { Renewable Energy } \\
\text { Directive } \\
\text { (2009/28/EC) }\end{array}$ & $\begin{array}{l}\text { sets national targets for renewable } \\
\text { energy production in each Member } \\
\text { State by } 2020 \\
\text { (National Renewable Energy Action } \\
\text { Plans) }\end{array}$ & $\begin{array}{l}\text { Dealing with applications for renewable } \\
\text { energy facilities; incorporating } \\
\text { appropriate policies in national } \\
\text { planning guidance and local } \\
\text { development plans }\end{array}$ \\
\hline $\begin{array}{l}\text { Urban Waste Water } \\
\text { Treatment Directive } \\
\text { (91/271/EEC) }\end{array}$ & $\begin{array}{l}\text { ensuring waste water from urban } \\
\text { settlements is treated before being } \\
\text { discharged }\end{array}$ & $\begin{array}{l}\text { Dealing with applications or allocating } \\
\text { sites for water management facilities }\end{array}$ \\
\hline $\begin{array}{l}\text { Waste Framework } \\
\text { Directive(2008/98/EC) }\end{array}$ & $\begin{array}{l}\text { pushing waste management } \\
\text { towards the priorities at the top of } \\
\text { the waste hierarchy and away from } \\
\text { landfill, with \% targets for particular } \\
\text { disposal routes } \\
\text { ([National] Waste Management } \\
\text { Plans) }\end{array}$ & $\begin{array}{l}\text { Dealing with applications for waste } \\
\text { management facilities, or allocating } \\
\text { sites in development plans; promoting } \\
\text { re-use of construction waste; Waste } \\
\text { Management Plans contributed } \\
\text { to/taken into account. }\end{array}$ \\
\hline $\begin{array}{l}\text { Water Framework } \\
\text { Directive(2000/60/EC) }\end{array}$ & $\begin{array}{l}\text { ensuring water bodies attain 'good } \\
\text { water status' } \\
\text { (River Basin Management Plans) }\end{array}$ & $\begin{array}{l}\text { Dealing with applications for waste } \\
\text { management facilities (or flood water } \\
\text { storage), or allocating sites in } \\
\text { development plans. Influencing the } \\
\text { form and location of development to } \\
\text { manage run off, flood risk and water } \\
\text { quality. RBMP contributed to/taken into } \\
\text { account. }\end{array}$ \\
\hline \multicolumn{3}{|c|}{ EU Directives with mainly procedural requirements } \\
\hline $\begin{array}{l}\text { Environmental Impact } \\
\text { Assessment Directive } \\
\text { (2011/92/EU, as } \\
\text { amended) }\end{array}$ & $\begin{array}{l}\text { Directing the environmental } \\
\text { information to be provided with an } \\
\text { application, to ensure that its } \\
\text { environmental effects can be } \\
\text { properly judged, and demonstrably } \\
\text { taking it into account in decisions }\end{array}$ & $\begin{array}{l}\text { Incorporating EIA requirements into the } \\
\text { application and decision-making } \\
\text { process for all eligible projects. }\end{array}$ \\
\hline $\begin{array}{l}\text { Seveso III Directive } \\
(2012 / 18 / E U)\end{array}$ & $\begin{array}{l}\text { Controlling major accident hazards } \\
\text { involving dangerous substances } \\
\text { through prevention, preparedness } \\
\text { and response; includes public rights } \\
\text { to information }\end{array}$ & $\begin{array}{l}\text { Can affect the siting of hazardous } \\
\text { facilities and proximity of sensitive } \\
\text { development }\end{array}$ \\
\hline $\begin{array}{l}\text { Strategic } \\
\text { Environmental } \\
\text { Assessment Directive } \\
(2001 / 42 / E C)\end{array}$ & $\begin{array}{l}\text { Directing the information on } \\
\text { significant environmental effects to } \\
\text { be provided alongside relevant } \\
\text { plans and programmes, to ensure } \\
\text { that their environmental effects can }\end{array}$ & $\begin{array}{l}\text { Incorporating SEA requirements into } \\
\text { the preparation and approval of local } \\
\text { development plans, and sectoral plans } \\
\text { and programmes that set the context } \\
\text { for project consents }\end{array}$ \\
\hline
\end{tabular}




\begin{tabular}{|l|l|l|}
\hline & $\begin{array}{l}\text { be properly assessed, and } \\
\text { demonstrably taking it into account } \\
\text { in decisions }\end{array}$ & \\
\hline
\end{tabular}

Source: authors; see also Wilkinson et al 1998. Note, we do not report on marine planning directives in this paper (i.e. Marine Strategy Framework Directive (2008/56/EC), The Maritime Spatial Planning Directive (2014/89/EU)) and acknowledge that there are other directives with some, albeit more limited, bearing on planning e.g. Energy Performance of Buildings Directive (2010/31/EU) and the Energy Efficiency Directive (2012/27/EU); and the Environmental Noise Directive (2002/49/EC). 
Table 2: Regulatory styles with EU environmental protection and UK planning

\begin{tabular}{|c|c|}
\hline Regulatory style & Key features \\
\hline $\begin{array}{l}\text { EU environmental } \\
\text { protection }\end{array}$ & $\begin{array}{l}\text { - Firm substantive environmental } \\
\text { - standards and targets } \\
\text { - Specific time frames for } \\
\text { - Durablementation } \\
\text { - Informed by environmental principles } \\
\text { - Robust machinery for monitoring and } \\
\text { - } \text { enforcement } \\
\text { - Open scope for complaints }\end{array}$ \\
\hline UK planning & $\begin{array}{l}\text { - } \quad \text { Discretion and flexibility } \\
\text { - } \quad \text { Balances environment against other } \\
\text { factors } \\
\text { - } \quad \text { Great scope for national governments } \\
\text { - } \quad \text { Limited senicy relatively swiftly } \\
\text { (environmental) purpose } \\
\text { - Limited scope for complaints, mostly } \\
\text { on procedural grounds }\end{array}$ \\
\hline
\end{tabular}


Figure 1: Scenarios for the planning-environment interface

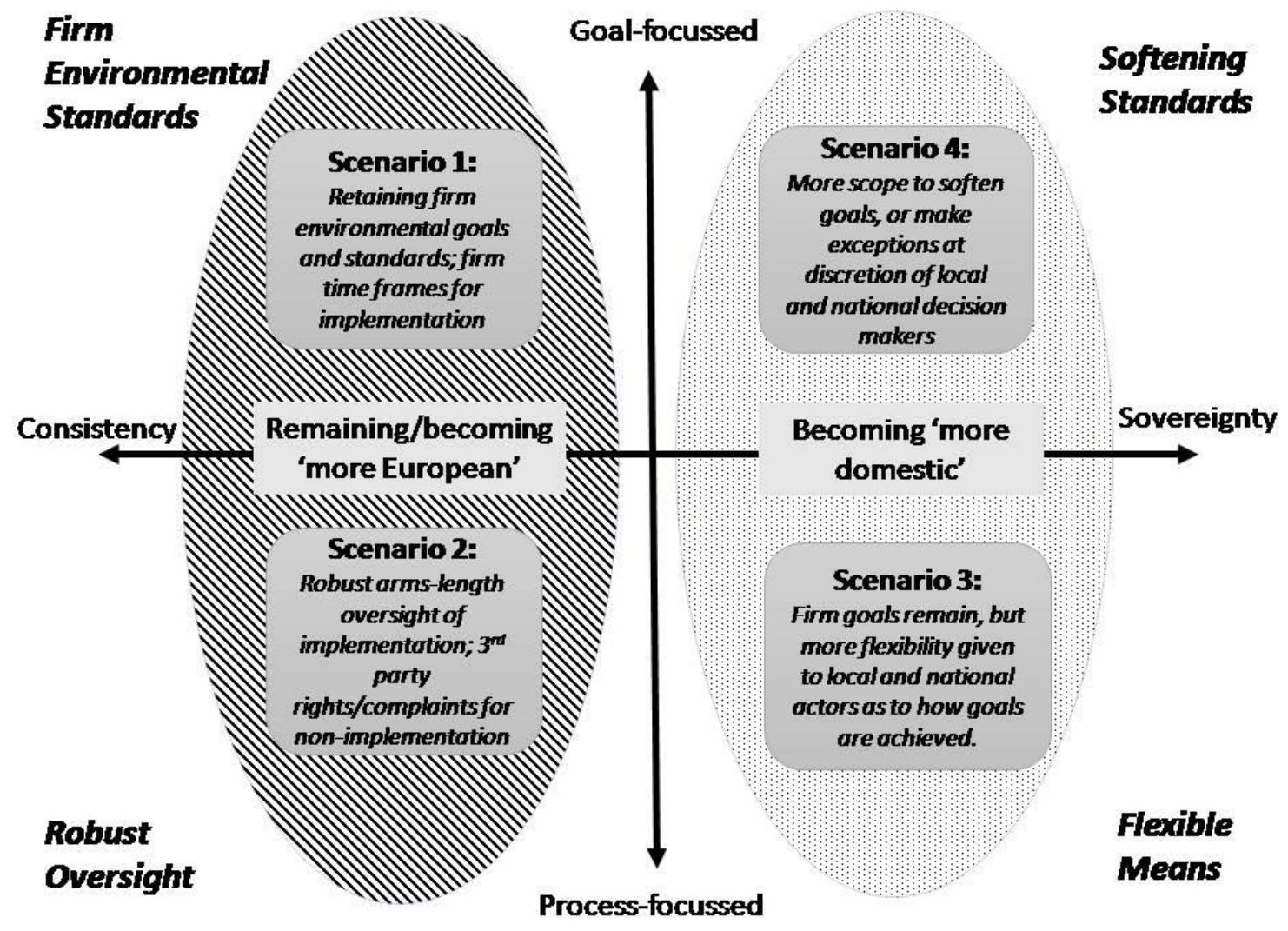


Figure 2: What shapes the effects of EU environmental legislation in planning?

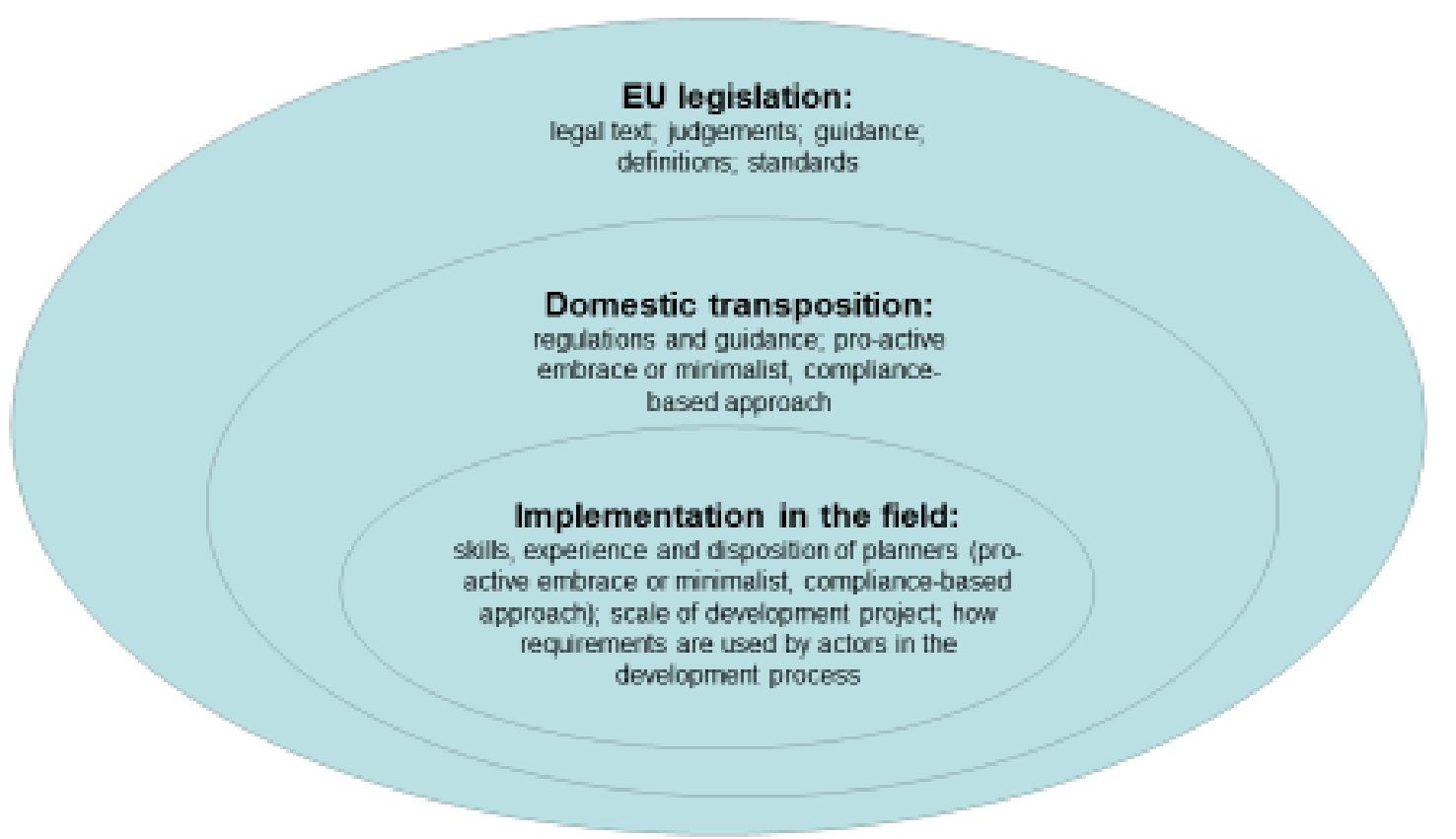

